\title{
Comments on Ectoparasites of Two Species of Microtus in Nebraska
}

\author{
ROBERT M. TIMM
}

Bell Museum of Natural History, University of Minnesota, Minneapolis, Minnesota

\begin{abstract}
The ectoparasitic fauna of Nebraskan Microtus pennsylvanicus and Microtus ochrogaster was examined to determine what species were present, the relative abundance of each species, sex, and developmental stage. Four species of mites of the family Laelapidae were found. Hyperlaelaps microti, the most abundant ectoparasite collected, and Androlaelaps fahrenholzi were obtained from both species of voles. Hirstionyssus isabellinus is reported from Nebraska for the first time on the basis of three specimens taken from M. pennsylvanicus. One adult female Hirstionyssus utahensis was collected from M. ochrogaster and constitutes the first record of this mite for Nebraska and on M. ochrogaster.

Dermacentor variabilis, the American dog tick, was the only tick taken during the study. Two species of fleas, Epitedia wennmani and Monopsyllus wagneri, were found on M. pennsylvanicus. The single species of louse obtained, Hoplopleura acanthopus, was collected only from M. pensylvanicus and is herein initially reported from Nebraska. Trans. Kans. Acad. Sci., 75 (1), 1972.
\end{abstract}

\section{Introduction}

Several articles have been published describing ectoparasites and their distribution on mammals, but little of this work has been done in the Great Plains region. Allred (1958) described mites on five species of Peromyscus in Utah. Kinsella and Pattie (1967) studied ectoparasites of small mammals, including Microtus montanus and Arvicola richardsoni, from the Beartooth Plateau in Wyoming. Populations of lice on Peromyscus maniculatus, Microtus pennsylvanicus, and Cletbrionomys gapperi in Minnesota were studied by Cook and Beer $(1955 ; 1958)$. In a review of the natural history of the prairie vole, Jameson (1947) included a list of the ectoparasites collected from Microtus ocbrogaster in Kansas. Rapp (1962) listed seven species of mites found on birds and mammals in Nebraska and Rapp and Gates (1957) published distributional notes for fleas obtained from Nebraskan Peromyscus and Blarina.

Considering the paucity of information on mammalian hostectoparasite relationships, I felt that a more comprehensive study of the ectoparasitic fauna associated with Microtus pennsylvanicus (Ord) would

Transactions of the Kansas Academy of Science, Vol. 75, No. 1, 1972. Published February 21, 1973. 
be elucidative. The purposes of this research were to determine what species of ectoparasites occur on $M$. pennsylvanicus and to estimate the relative abundance of each sex and developmental stage for each ectoparasitic specics.

\section{Materials and Methods}

Collections of specimens were made during the period of 18 October 1969-20 April 1970. The study site was a riparian habitat with a dense growth of mixed grasses located two miles south of Kearney, in Kearney County, Nebraska. Additionally, some ectoparasites were collected from specimens of $M$. ochrogaster collected incidentally at one mile east of Wilber, Saline County. All voles were caught in Sherman live traps using rolled oats for bait. Each vole was placed in a separate plastic bag, killed, tagged, and frozen until parasites could be removed. Preliminary attempts to remove ectoparasites included washing the host with non-sudsing detergent, rinsing the host, filtering the solution (Elzinga, 1967), and dissolving the skin in $\mathrm{KOH}$ (Cook, 1954), but the number of parasites retrieved was markedly less than was observed using the following technique. A triangular file was used to scrape and brush the skins (see Ellis, 1955) of 15 of the 17 voles studied. In addition, the voles were inspected thoroughly under a .7-3X dissecting microscope and parasites removed individually. This method appeared to result in a more complete removal of external parasites than did the previous methods.

\section{Accounts of Ectoparasites}

\section{(ACARI: Laelapidae) \\ Hyperlaelaps microti (Ewing)}

Hyperlaelaps microti was abundant on Microtus pennsylvanicus during the entire study period. One hundred and eighteen adult females, 31 adult males, and 47 deutonymphs of this species were collected from 15 $M$. pennsylvanicus during the investigation. These mites appeared to have no site preference, as they were collected from many locations on the hosts (Timm, 1972). A maximum of $61 \mathrm{H}$. microti and 15 lice (Hoplopleuridae: Hoplopleura acanthopus) was obtained from one host on 7 February 1970, with no apparent damage having been done to the host. Allred and Beck (1966) reported Microtus sp. to be the preferred host. Jameson (1947) found this mite on M. ochrogaster and Sigmodon bis. pidus in Kansas and on M. pennsylvanicus in New York. Lawrence et al. (1965) found H. microti on M. pennsylvanicus in Michigan. H. microti was reported to have been found on $M$. ochrogaster near Chadron, Dawes County, Nebraska, in 1956 (Rapp, 1962) and I have taken in from 
M. ocbrogaster in Saline County, Nebraska. Hyperlaelaps microti is considered an important vector of tularemia (Baker et al., 1956). Laelaps kocbi Oudemans is a name commonly used in literature for this species.

\section{Androlaelaps fabrenbolzi (Berlese)}

This cosmopolitan mite has been found on a variety of hosts (Baker et al., 1956), especially on mice of the genus Peromyscus. Four Androlaelaps fabrenbolzi, one adult female, one adult male, and two deutonymphs, were obtained from a $M$. pennsylvanicus captured on 16 December 1969 and are the only members of the species collected during this study (Timm, 1972). Numbers were insufficient to determine seasonal abundance and sex ratios. Baker et al. (1956) cited a study in Georgia where no appreciable seasonal change in abundance of this mite was found, but Allred (1958) noted a seasonal flucuation with population peaks from April through August. Lawrence et al. (1965) found this mite on M. pennsylvanicus in Michigan. Rapp (1962) reported that $A$. fabrenbolzi was taken on Peromyscus from several locations in Nebraska. He also found it on Spermophilus tridecemlineatus and M. ocbrogaster in Dawes County and on Blarina brevicauda in Knox County. I have obtained it from M. ochrogaster in Saline County.

\section{Hirstionyssus isabellinus (Oudemans)}

Two adult males were recovered from separate hosts during October, and one adult female was recovered in December (Timm, 1972). Hirstionyssus isabellinus is commonly associated with Hyperlaelaps sp. on voles (Allred and Beck, 1966). Herrin (1970) reported mites of this species on Microtus pennsylvanicus in Michigan, New York, Ohio, and Utah. Kinsella and Pattie (1967) found it on M. montanus and Arvicola richardsoni in Wyoming. There are no earlier published records for this mite from Nebraska. H. isabellinus is considered an important vector of tularemia (Baker et al., 1956).

Hirstionyssus utabensis Allred and Beck

One adult female Hirstionyssus utabensis was recovered from Microtus ochrogaster in Saline County on 9 November 1969. Specimens of Hyperlaelaps microti and Androlaelaps fabrenbolzi were taken from the same host. Herrin (1970) reported this species as being found on Peromyscus in California, Colorado, Iowa, Michigan, and Ohio. This is the first record of this mite in Nebraska and on $M$. ochrogaster. It was not taken from the $M$. pennsylvanicus obtained on the primary study area. 


\section{(ACARI: IXODIDAE) \\ Dermacentor variabilis (Say)}

The American dog tick, Dermacentor variabilis, was found on only two M. pennsylvanicus, one obtained on 19 April and the other on 20 April 1970. Three nymphs and 24 larvae were taken from just behind the ears of one host and 18 larvae were removed from the same area of the other. Morlan (1952) found D. variabilis on a variety of mammals throughout the year in Georgia. This tick has been reported on $M$. pennsylvanicus in Michigan (Lawrence et al., 1965) and West Virginia (Wilson, 1943). Jameson (1947) found only one nymph "attached to the scapular region of a prairie vole" in Kansas. D. variabilis is the principal vector of Rocky Mountain spotted fever in the central and eastern portion of the United States (Herms and James, 1961).

\section{(SipHONAPTERA: HySTRICHOPSYlLIDAE)}

\section{Epitedia wennmani (Rothschild)}

Three specimens of Epitedia wennmani, a common flea found on microtine and cricetine rodents, were obtained from $M$. pennsylvanicus during the study. One was taken on 8 November and two were taken from separate hosts on 16 December 1969. Rapp and Gates (1957) collected this flea on Peromyscus leucopus, P. maniculatus, and Blarina brevicauda from various locations throughout Nebraska. Holland and Benton (1968) found it on M. pennsylvanicus in Pennsylvania and Jameson (1947) reported it to be common on $P$. leucopus but rare on M. ochrogaster in Kansas. Stark (1959) reported finding this flea on M. pennsylvanicus in Utah, where he considered it a possible vector of plague.

\section{(Siphonaptera: Ceratophyllidae) \\ Monopsyllus wagneri (Baker)}

Monopsyllus wagneri was found on two $M$. pennsylvanicus during the study, one taken on 18 October 1969 and one on 19 April 1970. Rapp and Gates (1957) reported it on Peromyscus leucopus and $P$. maniculatus from several locations in Nebraska. Kinsella and Pattie (1967) found this flea on P. maniculatus and Spermopbilus lateralis from the Beartooth Plateau in Wyoming and it was found on Peromyscus maniculatus, $P$. boylii, and Microtus longicaudus in California (Jameson and Brennan, 1957). Stark (1959) considered this flea a possible vector of plague in Utah. 


\section{(ANoplura: Hoplopleuridae)}

Hoplopleura acanthopus (Burmeister)

Seventy six specimens of Hoplopleura acanthopus were found on seven M. pennsylvanicus during the period from 7 November to 20 April. Numbers of lice per vole ranged from one to 38. Seventy-one second and third instars were collected during the study, three first instars were found during the period from February to April, and one adult female and one adult male were taken in November. $H$. acanthopus is considered a ubiquitous parasite on microtine rodents. Ferris (1921) obtained it from Microtus in England and continental Europe. Cook and Beer (1955; 1958) have done extensive population studies of $H$. ancanthopus on M. pennsylvanicus in Minnesota. This is the first published record of the species from Nebraska.

\section{Acknowledgments}

I thank Drs. Edwin F. Cook, Cluff E. Hopla, James E. Keirans, Frank J. Radovsky, and Nixon Wilson for assistance in verification and identification of the ectoparasites. Dr. Harold G. Nagel assisted in many aspects of this research and Dr. Elmer C. Birney provided editorial assistance in preparation of the manuscript.

\section{References}

Allred, D. M. 1958. Mites found on mice of the genus Peromyscus in Utah. IV. Families Laelaptidae and Phytoseiidae (Acarina). Pan-Pacific Entomol., 34:17-32.

Allred, D. M., and D. E. BeCK. 1966. Mites of Utah Mammals. Brigham Young Univ. Sci. Bull., Biol. Ser., 8:1-123.

Bakfr, E. W., T. M. Evans, D. J. Gould, W. B. Hull, and H. L. Keegan. 1956. A manual of parasitic mites of economic importance. Tech. Publ. Natl. Pest Control Assoc., 170 pp.

Cook, E. F. 1954. A modification of Hopkin's technique for collecting ectoparasites from mammalian skins. Entomol. News, 65:35-37.

Cook, E. F., and J. R. BeEr. 1955. The louse populations of some cricetid rodents. Parasitology, 45:409-420.

COOK, E. F., and J. R. BeER. 1958. A study of louse populations on the meadow vole and deer mouse. Ecology, 39:645-659.

ElLIS, L. L., JR. 1955. A survey of the ectoparasites of certain mammals in Oklahoma. Ecology, 36:12-18.

ElziNGA, R. J. 1967. A laboratory manual for acarology. Kansas State Univ. (mimeo.), 151 pp.

FERRIS, G. F. 1921. Contributions toward a monograph of the sucking lice. Stanford Univ. Publ., Univ. Ser., Biol. Sci., 2(2):1-133.

Herms, W. B., and M. T. James. 1961. Medical entomology. Macmillan Co., New York, $x i+616$ pp.

Herrin, C. S. 1970. A systematic revision of the genus Hirstionyssus (Acari: Mesostigmata) of the nearctic region. J. Med. Entomol., 7:391-437.

Holland, G. P., and A. H. Benton. 1968. Siphonaptera from Pennsylvania mammals. Amer. Midland Nat., 80:252-261. 
JAMESON, E. W., JR. 1947. Natural history of the prairie vole (Mammalian genus Microtus. Univ. Kansas Publ., Mus. Nat. Hist., 1:125-151.

JAMEson, E. W., JR., and J. M. Brennan. 1957. An environmental analysis of some ectoparasites of small forest mammals in the Sierra Nevada, California. Ecol. Monog., 27:45-54.

Kinsella, J. M., and D. L. Pattie. 1967. Ectoparasites of small mammals of the alpine Beartooth Plateau, Wyoming. Canadian J. Zool., 45:233-235.

Lawrence, W. H., K. L. Hays, and S. A. Graham. 1965. Arthropodus ectoparasites from some northern Michigan mammals. Occas. Papers Mus. Zool., Univ. Michigan, 639:1-7.

Morlan, H. B. 1952. Host relationships and seasonal abundance of some southwest Georgia ectoparasites. Amer. Midland Nat., 48:74-93.

RAPP, W. F., JR. 1962. Distributional notes on parasitic mites. Acarologia, $4: 31-33$.

RAPp, W. F., JR., and D. B. Gates. 1957. A distributional check-list of the fleas of Nebraska. J. Kansas Entomol. Soc., 30:50-53.

StARK, H. E. 1959. The Siphonaptera of Utah. . . United States Dept. Health Education \& Welfare, Public Health Service, Atlanta, Georgia, xiii + $239 \mathrm{pp}$.

Timm, R. M. 1972. Mites (Acari: Laelapidae) parasitic on the meadow vole, Microtus pennsylvanicus. Acarologia, in press.

Wilson, L. W. 1943. Some mammalian ectoparasites from West Virginia, J. Mammal., 24:102. 